\title{
Teamwork: Assessment of teamwork competence in higher education
}

Navarro, Jose ${ }^{\mathrm{a}}$; Bosch, Josep Lluis ${ }^{\mathrm{b}}$; Palacín, Maria ${ }^{\mathrm{a}}$; Solé, Marina ${ }^{\mathrm{c}}$; Berger, Rita ${ }^{\mathrm{a}}$; Leiva, David ${ }^{\mathrm{a}}$; Ceppi, Francesca and Castellano, Júlia ${ }^{\mathrm{a}}$

${ }^{a}$ Department of Social Psychology and Quantitative Psychology, University of Barcelona, Spain, ${ }^{b}$ Department of Sociology, University of Barcelona, Spain, ${ }^{c}$ Department of Economics, University of Barcelona, Spain.

\begin{abstract}
Teamwork is both a competence highly demanded among workers and an academic field with an extensive specialized literature. Based on this knowledge that comes from the study of organizational behavior, this communication presents a model to understand teamwork in higher education settings. The theoretical model considers structural components (i.e., task interdependence and task uncertainty), processes (i.e., team development and team climate for learning) and results (i.e., team effectiveness). Moreover, an assessment tool (and attitudinal questionnaire with 42 items-Likert scale with a range from 1 to 7) is also presented to measure these critical components that can allow us to distinguish between effective and ineffective teams in higher education. Preliminary results of the application of these tools to 18 team students show good consistency values of the scales used being able to distinguish among teams. Additionally, we propose a procedure to obtain aggregated measures per group from the members' responses considering the degree of agreement among them.
\end{abstract}

Keywords: Teamwork; aggregated team measures; competence assessment; higher education. 


\section{Introduction}

Teamwork is a general competence included in the training plans of different undergraduate studies. For example, it is one of the general competences that we can see in the majority of the undergraduate studies at the University of Barcelona, where this competence is defined as the ability to collaborate with others and contribute to a common project, to collaborate in interdisciplinary teams and multi-cultural teams, and to participate in conflict resolution within the team. Additionally, teamwork is also a competence highly demanded in labor market. The reason behind this is simple: most jobs today have become jobs in which knowledge is managed. The work has ceased to be manual and has become to be related to knowledge activities and about the skills to manage it. For this, the use of a small group of workers who have to create, use or modify that knowledge is an adaptive advantage in relation to the classic designs of individual posts. A small number of people with differentiated roles has more resources (i.e., knowledge, skills) to deal with these tasks of knowledge management (e.g., Kozlowski \& Bell, 2003); for this reason organizations are now referred to as multi-team systems (Zaccaro, et al., 2011).

This is also why the team science, based on disciplines such as social psychology or sociology, has experienced an important development in recent years. Now we have extensive knowledge about how to design effective work teams (e.g., Salas, 2015; West, 2012). This knowledge is regularly applied in the team training programs, especially in sectors such as health, R\&D, military or sports, and it is also applied in more classic organizations dedicated to production or services (e.g., automobile industry, hotels, etc.; e.g., Meneses \& Navarro, 2015).

The objectives of this research will be: 1) to apply current knowledge from team science to understand teamwork competence in higher education settings, 2) to adapt existing assessment tools to the type of teams regularly used in higher education, 3) to generate knowledge about the characteristics of effective teams of students.

\section{A model to understand teamwork}

For the development of teamwork competence, the attention must be paid both to psychosocial aspects (e.g., the relationships established among team members) and to specific characteristics of the task addressed by the team. Usually, this second aspect is systematically forgotten assuming that any task is possible to execute in teams and, therefore, when the performance of a team is deficient is attributed to the members that have not sufficiently developed the competence to work as a team. But this is not always the case; frequently happens that teams do not work as such for the simple reason that the 
task to be tackled can be done effectively without the use of teams, in other words, without putting the teamwork competence into play.

To understand teams, team science has a pragmatic starting point: it is interested in knowing why some teams are more effective than others. What is interesting for us here is what the literature proposes about how some teams become more effective than others. This is often referred to as IPO models (inputs, processes and outputs) and IMOI models (input models, mediators, outputs and new inputs, inputs-mediators-outputs-inputs). Paying attention to these inputs and processes or mediators the literature usually repeats a series of key aspects to understand effective teams. Let us describe these in detail. We will follow the model proposed by Navarro et al. (2011; see Figure 1) adding some elements that we consider interesting taking into account the type of teams (groups of university students) as well as the context in which these take place (an academic context of learning).

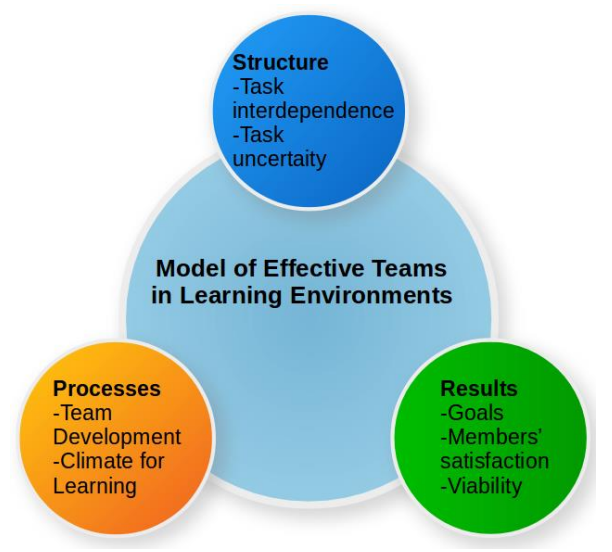

Figure 1. Model of effective teams in learning environment (adapted from Navarro et al., 2011).

\subsection{Team structure}

Teams are always designed to do something, to accomplish some tasks. Team tasks can have certain characteristics that require that members behave in one way or another, for example in a more or less coordinated way. Tasks are of paramount importance in designing effective teams because, as repeated research teach us (e.g., Salas et al., 2009), not all tasks require teamwork and, when this happens, teams do not work as real teams because they not need to do it. For example, if a task can be decomposed into individual subtasks whose effective implementation does not require interaction with others, teamwork will not occur and teamwork competence becomes unnecessary. In other words, teams are not always necessary and special attention must be paid to what types of tasks require a coordinate effort of members. This aspect is critical because if we are interested in 
the development of teamwork competence the first thing to do is to design tasks that really require teamwork.

In this regard the literature (e.g., Gladstein, 1984, Navarro et al., 2011) consider two key aspects of the tasks: their levels of interdependence and uncertainty. Interdependence refers to the direction of the work flow that makes that team members have to interact, to a lesser or greater degree, with each other to achieve the task successfully. For its part, the uncertainty refers to the existence of unclear links between what the team has to do and what results it will get. Uncertainty is high when tasks are unclear (there are not knowledge about what to do and how), diverse, novel and there are sub-tasks that are incompatible each other. Tasks are really team tasks when both interdependence and uncertainty are high. In these conditions, a real work team is required to face with the tasks with guarantees of success.

In addition to the tasks, other structural characteristics are important, such as size or diversity. We know that size influences on team phenomena that may imply a negative influence on effectiveness. This is the case, for example, of the phenomenon called social loafing that appears more easily in large groups. And we also know that diversity introduces an added complexity to the team that has to know how to manage it. Diversity sometimes influences communication between members, making it difficult to have members with different social norms in this respect. And, on the other hand, diversity can be as well an accelerator in solving certain types of tasks, such as creative ones.

\subsection{Team processes}

Team science has found that there are many cognitive (e.g., mental models, transactive memory, team learning), affective (e.g., team potency, cohesion, group emotion) and behavioral processes (e.g., communication, coordination) that are important for understanding teamwork. In addition, there are also emerging processes (e.g., group development, group climate) that are also determinants of team performance. Taking into account the strength relationships previously founded in the literature (see Kozlowski \& Bell, 2003) and the specific context in which we are interesting in we will choose the following processes to consider: team development and team climate for learning.

Team development refers to the maturity of the group. Not all teams reach the same level of maturity. The highly developed teams are those in which their members interact regularly, coordinate resources, orientate their behavior towards collective achievement and in which members feel identified with the team (Meneses et al., 2008). On the other hand, team climate for learning (e.g., Brodbeck et al., 2010) refers to shared perceptions within team members that promote collective learning. Within this climate of the team for learning, we 
include some dimensions that we consider particularly interesting in this project, such as mutual trust among members, openness to share ideas, or equality in the exercise of influence among members.

\subsection{Team effectiveness}

Although there is not unanimity among authors about what should be consider team effectiveness, the normative model of Hackman (1987) is usually considered the most appropriate. According to this proposal a team is effective when it achieves three things: 1) to achieve the objectives for which it was designed; 2) to satisfy the needs of its members, and 3 ) to be viable or sustainable over time. If team fails in the achievement of one of these elements team is considered as ineffective.

\section{Measuring the components of the model}

Once we have a theoretical model useful to understand why some teams are more effective than others (i.e., because they are more developed; because their tasks are more interdependent; etc.), we can measure all of these components to obtain an assessment in team of students in higher education.

In Table 1 we present all the instruments that we have adapted here for our purposes. All of these instruments have a long tradition in team science showing good reliability and validity results in the studies that we mention as well. 
Teamwork: Assessment of teamwork competence in higher education

Table 1. Instruments to assess the components of the model of effective teams

\begin{tabular}{|c|c|c|c|}
\hline Component & Source & Characteristics & Example of items \\
\hline $\begin{array}{l}\text { Task } \\
\text { interdependence }\end{array}$ & $\begin{array}{l}\text { Van der Vegt } \\
\text { and Janssen, } \\
2002\end{array}$ & $\begin{array}{l}7 \text { items-Likert } \\
\text { format }\end{array}$ & $\begin{array}{l}\text { 'I need information and suggestions } \\
\text { from colleagues to do my homework } \\
\text { well' }\end{array}$ \\
\hline Task uncertainty & $\begin{array}{l}\text { Navarro et al., } \\
2011\end{array}$ & $\begin{array}{l}18 \text { items- } \\
\text { Likert format }\end{array}$ & $\begin{array}{l}\text { 'We find it confusing to know what it } \\
\text { is that we should get with our work' }\end{array}$ \\
\hline $\begin{array}{l}\text { Team } \\
\text { development }\end{array}$ & $\begin{array}{l}\text { Navarro et al., } \\
2015\end{array}$ & $\begin{array}{l}8 \text { items-Likert } \\
\text { format }\end{array}$ & $\begin{array}{l}\text { 'Members feel committed to meeting } \\
\text { group goals' }\end{array}$ \\
\hline $\begin{array}{l}\text { Team climate } \\
\text { for learning }\end{array}$ & $\begin{array}{l}\text { Brodbeck et al, } \\
2010\end{array}$ & $\begin{array}{l}9 \text { items-Likert } \\
\text { format }\end{array}$ & $\begin{array}{l}\text { 'My group helps me in my individual } \\
\text { learning' }\end{array}$ \\
\hline $\begin{array}{l}\text { Team } \\
\text { effectiveness }\end{array}$ & $\begin{array}{l}\text { Navarro et al., } \\
2011\end{array}$ & $\begin{array}{l}11 \text { items- } \\
\text { Likert format }\end{array}$ & $\begin{array}{l}\text { 'We are effective at accomplishing our } \\
\text { tasks' }\end{array}$ \\
\hline
\end{tabular}

\section{A first study: Main results}

We have the opportunity to applied these instruments to 18 students' teams in the Bachelors degrees of Psychology and Sociology, at the University of Barcelona. When applied the tools to team of students that work in a team during certain time (i.e., a semester) to cope with an assignment put by, and assessed by as well, the professor. The main descriptive results can be found in Table 2. Additionally, in Figure 2 we represent the teams' average values in each component of the model. 
Navarro, J.; Bosch, J.L.; Palacín, M.; Solé, M.; Berger, R.; Leiva, D.; Ceppi, F. and Castellano, J.

Table 2. Descriptive results, and correlations, of the team model application

\begin{tabular}{lccccccccc}
\hline Variable & $M$ & $S D$ & $\min$ & $\max$ & 1 & 2 & 3 & 4 & 5 \\
\hline 1. Task interdependence & 3.18 & 0.88 & 0 & 5 & 1 & & & \\
2. Task uncertainty & 3.53 & 0.95 & 0 & 5 & 0.18 & 1 & & \\
3. Team development & 3.43 & 1.01 & 0 & 5 & -0.03 & $0.48^{*}$ & 1 & & \\
4. Team climate for learning & 3.47 & 0.95 & 0 & 5 & -0.32 & 0.22 & $0.75^{* *}$ & 1 & \\
& & & & & & & & & \\
\hline 5. Team effectiveness & 3.60 & 1.08 & 0 & 5 & -0.39 & 0.09 & $0.68^{* *}$ & $0.93^{* *}$ & 1
\end{tabular}

Notes: $\mathrm{N}=18$ students' teams; ${ }^{*} \mathrm{p}<0.05 ; * * \mathrm{p}<0.01$

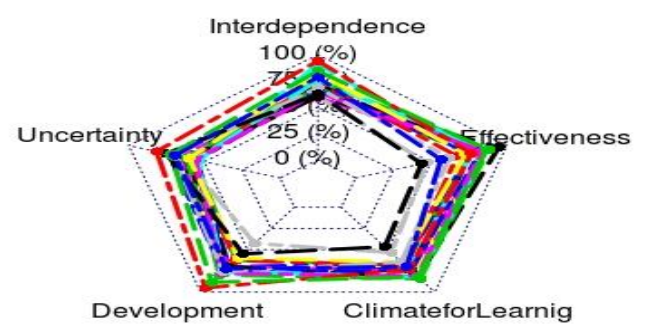

Figure 2. Average values in team model components in 18 students' teams

Team processes measured (i.e. development and climate for learning) are clearly related with team effectiveness. On the other hand, tasks measures (i.e., interdependence and uncertainty) seem to be unrelated with that effectiveness. Moreover, considering Figure 2 we can say that the instruments applied are useful to distinguish among the different students' teams.

\subsection{Procedure to aggregate data}

Measuring team constructs considering the perception of team members introduces a challenge in the assessment in the sense that we have to create an team aggregate measure from members' perceptions, in other words, from individual perceptions. To do this, it is needed to study previously if there is an agreement among the perception of team members. 
If this happen, we can obtain a reliable aggregated measure of the team (e.g., the mean or median values among individual perceptions).

To study this agreement we recommend follow the suggestions made by Bliese (2000) and to apply the intraclass correlation coefficients (ICC) or, alternatively, the average mean/median deviation index (AMD). Bliese provides guidelines about how to calculate and interpret both measures in team studies. In the application showed before all the teams obtained ICC values that indicated agreement. But, in other applications, when agreement does not happen it would be relevant to study the causes of this disagreement and to study as well the possibility of the existence of different subgroups inside each team.

\section{Conclusions and future direction}

Teamwork competence is so relevant nowadays in academic and labor settings. Being able to measure how well the students work in teams is the first step after study if this competence is developing over the years in which the students ares in our universities. At this point, the use of assessment in different waves (e.g., one per semester) doing a follow up study with the same students can be very useful to understand how team competence evolve over time, and to check if as professor we really achieve that our students learn how to work in teams. Moreover, if we focus on competences development, we must have tools to assess these competences properly.

The next step for this research can be twofold. First, to convert the tools in a possible rubric than can be apply by an observant of the team in real time. This means to create an observational system than can be used for observers (e.g. the professor) to assess a team of students while they are working together (e.g., making a public presentation). And second, to study if, as we guess, students' teams that are more effective have, at the same time, better results in terms of academic performance (e.g. better final marks). 


\section{References}

Bliese, P. D. (2000). Within-group agreement, non-independence, and reliability. Implications for data aggregation and analysis. En K. J. Klein \& S. W. Kozlowski (Eds.), Multilevel theory, research, and methods in organizations. Foundations, extensions, and new directions (pp. 349-381). San Francisco, CA: Jossey-Bass Inc.

Brodbeck, F. C., Guillaume, Y. R. F. \& Winkler, M. (2010). Team Climate for Learning in Higher Education. WOP Working Paper No. 2010/1.

Gladstein, D. L. (1984). Groups in context: A model of task group effectiveness. Administrative Science Quarterly, 29, 499-517.

Hackman, J. R. (1987). The design of work teams. En J. W. Lorsch (Ed.), Handbook of organizational behavior (pp. 315-342). Englewood Cliffs, NJ: Prentice-Hall.

Kozlowski, S. W. J. \& Bell, B. S. (2003). Work groups and teams in organizations. En W. C. Borman, D. R. Ilgen y R. J. Klimoski (Eds.), Handbook of psychology: Industrial and organizational psychology, 12, 333-375. London: Wiley.

Meneses, R. \& Navarro, J. (2015). ¿Cómo mejorar la eficacia de los equipos a través de los procesos grupales?. Un ejemplo en la industria automotriz. Papeles del Psicólogo, 36, 224-229.

Meneses, R., Ortega, R., Navarro, J. \& Quijano, S. D. de (2008). Criteria for assessing the level of group development (LGD) of work groups. Groupness, entitativity, and groupality as theoretical perspectives. Small Group Research, 39, 492-514.

Navarro, J., Meneses, R., Miralles, C., Moreno, D. I. \& Loureiro, V. (2015). What distinguish teams from social aggregates? A tool to assess the group development. Anales de Psicología, 31, 921-929. doi: 10.6018/analesps.31.3.183831

Navarro, J., Quijano, S. D. de, Berger, R. \& Meneses, R. (2011). Grupos en las organizaciones: Herramienta básica para gestionar la incertidumbre y ambigüedad crecientes. Papeles del Psicólogo, 32, 17-28.

Salas, E. (2015). Team training essentials. A research-based gruide. London, UK: Taylor \& Francis Ltd.

Salas, E., Goodwing, G. F. \& Burke, C. S. (2009). Team effectiveness in complex organizations. Cross-disciplinary perspectives and approaches. New York, NY: Psychology Press.

Van der Vegt, G. S. \& Janssen, O. (2002). Joint impact of interdependence and group diversity on innovation. Journal of Management, 29, 729-751. doi: 10.1016/S01492063_03_00033-3

West, M. (2012). Effective teamwork. Practical lessons from organizational research. London: UK: Blackwell. 